\title{
The effect of L-arginine on guinea-pig and rabbit airway smooth muscle function in vitro
}

\section{A.C. Perez 1 , W. Paul ${ }^{2}$, S. Harrison' ${ }^{2}$, C.P. Page ${ }^{2}$ and D. Spina ${ }^{3}$}

\author{
1Departamento de Ciências Fisiológicas, Universidade Estadual de São Paulo, \\ São José dos Campos, SP, Brasil \\ 2Department of Pharmacology, King's College London, London, UK \\ ${ }^{3}$ The Sackler Institute of Pulmonary Pharmacology, \\ Department of Thoracic Medicine, King's College London, London, UK
}

\section{Correspondence \\ A. Perez \\ C.T.A. H 17 B 116 \\ 12228-530 São José dos Campos, SP \\ Brasil \\ A.C Perez was the recipient of CNPq and British Council fellowships. Publication supported by FAPESP.}

Received August 26, 1997 Accepted March 4, 1998

\section{Abstract}

We have investigated the effects of L-arginine, D-arginine and Llysine on airway smooth muscle responsiveness to spasmogens in vitro. Both L-arginine and D-arginine $(100 \mathrm{mM})$ significantly reduced the contractile potency and maximal contractile response to histamine but not to methacholine or potassium chloride in guinea-pig epithelium-denuded isolated trachea. Similarly, the contractile response to histamine was significantly reduced by L-arginine $(100 \mathrm{mM})$ in rabbit epithelium-denuded isolated bronchus. The amino acid L-lysine (100 $\mathrm{mM}$ ) failed to significantly alter the contractile potency of histamine in guinea-pig isolated trachea $(\mathrm{P}>0.05)$. In guinea-pig isolated trachea precontracted with histamine, both L-arginine and D-arginine produced a concentration-dependent relaxation which was not significantly altered by epithelium removal or by the presence of the nitric oxide synthase inhibitor, $\mathrm{N}^{\mathrm{G}}$-nitro L-arginine methyl ester (L-NAME; $50 \mu \mathrm{M})$. Thus, at very high concentrations, arginine exhibit a noncompetitive antagonism of histamine-induced contraction of isolated airway preparations that was independent of the generation of nitric oxide and was not dependent on charge. These observations confirm previous studies of cutaneous permeability responses and of contractile responses of guinea-pig isolated ileal smooth muscle. Taken together, the data suggest that high concentrations of arginine can exert an anti-histamine effect.

\section{Introduction}

We have previously demonstrated the ability of both L-arginine and D-arginine, but not L-lysine (all $10 \mu \mathrm{mol} / \mathrm{site}$ ) to significantly reduce histamine- but not bradykinininduced plasma protein extravasation in guinea-pig skin (1). Furthermore, L-arginine and D-arginine but not L-lysine (all $100 \mathrm{mM}$ ) attenuated histamine- but not bradykinin-

\author{
Key words \\ - L-Arginine \\ - D-Arginine \\ - L-Lysine \\ - Histamine \\ - $\mathrm{H}_{1}$ receptors
}

induced contraction of guinea-pig isolated ileum (1). These data suggested the ability of very high concentrations of both L-arginine and D-arginine to act as functional antagonists against $\mathrm{H}_{1}$ receptor-mediated contraction (1). This is consistent with an earlier study demonstrating that arginine inhibits histamine- and, to a lesser extent, kallidininduced responses in guinea-pig ileum and uterus (2). However, L-arginine at the same 
high concentration had no significant effect on histamine-induced plasma protein extravasation in rabbit skin (3). In vivo and in vitro studies of guinea-pig airway responsiveness to histamine have shown enhancement of responses following treatment with nitric oxide synthase inhibitors and abrogation of this enhancement by concomitant treatment with L-arginine (4). In the present study, we have investigated the ability of high concentrations of arginine to alter the biological action of histamine on airway smooth muscle preparations in vitro.

\section{Material and Methods}

\section{Tissue preparation}

Albino guinea-pigs (300-500 g) were killed by cervical dislocation and the trachea was removed and placed in cold $\left(4^{\circ} \mathrm{C}\right)$ KrebsHenseleit solution aerated with $95 \% \mathrm{O}_{2}$ and $5 \% \mathrm{CO}_{2}$ and containing the cyclooxygenase inhibitor indomethacin $(5 \mu \mathrm{M})$. Rabbits (NZW, $2-3 \mathrm{~kg}$ ) were killed by an overdose of pentobarbitone $(60 \mathrm{mg} / \mathrm{ml})$ and the main bronchus was removed and placed in cold oxygenated Krebs-Henseleit solution. The epithelium can influence guinea-pig tracheal (5) and rabbit bronchial (6) smooth muscle responsiveness to spasmogens. Thus, the epithelium was removed from all preparations unless otherwise specified. Epithelium was removed with a cotton wool probe and its absence and presence were assessed histologically as described previously (5).

Guinea-pig tracheal and rabbit bronchial rings were suspended in 10-ml organ baths under an optimal tension of $1 \mathrm{~g}$ in KrebsHenseleit solution containing indomethacin (5 $\mu \mathrm{M})$ at $37^{\circ} \mathrm{C}$ and aerated with $95 \% \mathrm{O}_{2}$ and $5 \%$ $\mathrm{CO}_{2}$. Changes in tension were measured isometrically using an FTO3 transducer connected to an Electromed amplifier and chart recorder (Grass Instruments Co., Beds, UK). Tissues were equilibrated for $30 \mathrm{~min}$ and the KrebsHenseleit solution changed every $10 \mathrm{~min}$.
Methacholine $(10 \mu \mathrm{M})$ was added to the bath to induce maximal contraction. After the contractile response had reached a plateau, the tissues were washed 5 times over a 15-min period and allowed to equilibrate for a further $30 \mathrm{~min}$.

\section{Functional studies}

Guinea-pig trachea. Cumulative concentration-effect curves for histamine $(0.01 \mu \mathrm{M}$ $1 \mathrm{mM})$, methacholine $(0.01-100 \mu \mathrm{M})$ and potassium chloride $(10-160 \mathrm{mM})$ were constructed before and following 20-min incubation in the presence of L-arginine, D-arginine or L-lysine (10-100 mM). Tissues were then washed 5 times over a 15 -min period to remove the amino acids and tissues were allowed to equilibrate for a period of $30 \mathrm{~min}$ before concentration-effect curves for these spasmogens were constructed. In control tissue, concentration-response curves to the spasmogens were performed in the absence of the amino acids.

The effect of L-arginine (100 $\mathrm{mM})$ and L-lysine $(100 \mathrm{mM})$ on the $\mathrm{pH}$ of KrebsHenseleit solution at room temperature and aerated with $95 \% \mathrm{O}_{2}$ and $5 \% \mathrm{CO}_{2}$ was analysed using an ABL 30 blood gas analyser.

In other studies, epithelium-intact and denuded tracheal preparations were contracted with histamine $\left(\mathrm{EC}_{50}\right)$ in the absence or presence of the nitric oxide synthase inhibitor $\mathrm{N}^{\mathrm{G}}$-nitro L-arginine methyl ester (LNAME; $50 \mu \mathrm{M})$. Cumulative concentrations of L-arginine, D-arginine and L-lysine (1$100 \mathrm{mM}$ ) were superimposed on this histamine contractile response.

Rabbit bronchus. Cumulative concentration-effect curves for histamine $(0.1 \mu \mathrm{M}-1$ $\mathrm{mM}$ ) were performed in the absence and following 20-min incubation in the presence of L-arginine (100 mM).

Contractile responses were expressed as a percentage of the maximum response observed in the control tissue. Thus, $\mathrm{EC}_{50}$ and $\mathrm{EC}_{30}$ refer to the concentration of agonist 
which gives $50 \%$ and $30 \%$, respectively, of the maximum response observed in the control tissue.

\section{Data analysis}

Contractile responses to methacholine, histamine and potassium chloride were expressed as a percent of the maximal response (Emax) to the spasmogens obtained prior to incubation of airway preparations with the amino acids. The concentration of agonist that contracted guinea-pig tracheal preparations to $30 \%$ Emax $\left(\mathrm{EC}_{30}\right)$ was used as a measure of contractile agonist potency. The concentration of L- and D-arginine that reversed histamine-contracted tissue by $50 \%$ $\left(\mathrm{EC}_{50}\right)$ was used as a measure of relaxant agonist potency. Contractile and relaxant potency was expressed as the geometric mean together with $95 \%$ confidence limits. Tension values are represented as the arithmetic mean and standard error of the mean. The Student paired and non-paired $t$-test was performed to test significance between means. Data were considered statistically significant if $\mathrm{P}<0.05$.

\section{Drugs}

Indomethacin, L-NAME, acetyl- $\beta$-methylcholine chloride (methacholine chloride), histamine dihydrochloride, L-arginine, Darginine, L-lysine hydrochloride were all from Sigma (St. Louis, MO). All drugs were dissolved in Krebs-Henseleit solution of the following composition: $117.6 \mathrm{mM} \mathrm{NaCl}, 5.4$ $\mathrm{mM} \mathrm{KCl}, 0.57 \mathrm{mM} \mathrm{MgSO}_{4} .7 \mathrm{H}_{2} \mathrm{O}, 1.03 \mathrm{mM}$ $\mathrm{KH}_{2} . \mathrm{PO}_{4}, 25.0 \mathrm{mM} \mathrm{NaHCO} 3,11.1 \mathrm{mM}$ glucose and $2.5 \mathrm{mM} \mathrm{CaCl} 2 \cdot 2 \mathrm{H}_{2} \mathrm{O}$.

\section{Results}

\section{Guinea-pig trachea: contractile responses}

Histamine. The contractile potency of histamine was not significantly altered in the absence or presence of $\mathrm{L}$-arginine (10 and 30 $\mathrm{mM} ; \mathrm{P}>0.05$ ) (data not shown). In contrast, $\mathrm{L}$-arginine $(100 \mathrm{mM})$ significantly reduced the contractile potency in response to histamine $\left(\mathrm{EC}_{30}, 95 \%\right.$ confidence limits; control $0.7 \mu \mathrm{M}(0.6-1.2), \mathrm{N}=6 v s$ L-arginine 100 $\mu \mathrm{M}$ (40-250), $\mathrm{N}=6, \mathrm{P}<0.05$, Figure 1A). The maximum contractile response (Emax) to histamine was also significantly reduced in the presence of L-arginine (control $500 \pm$ $150 \mathrm{mg}$ vs L-arginine $200 \pm 50 \mathrm{mg}, \mathrm{N}=6$, $\mathrm{P}<0.05)$. The contractile potency $(\mathrm{P}>0.05)$ and Emax $(\mathrm{P}>0.05)$ of histamine were not significantly different from controls after washing tissues to remove L-arginine.

D-arginine ( 10 and $30 \mathrm{mM} ; \mathrm{P}>0.05$ ) failed to significantly alter the contractile potency of histamine (data not shown). In contrast,

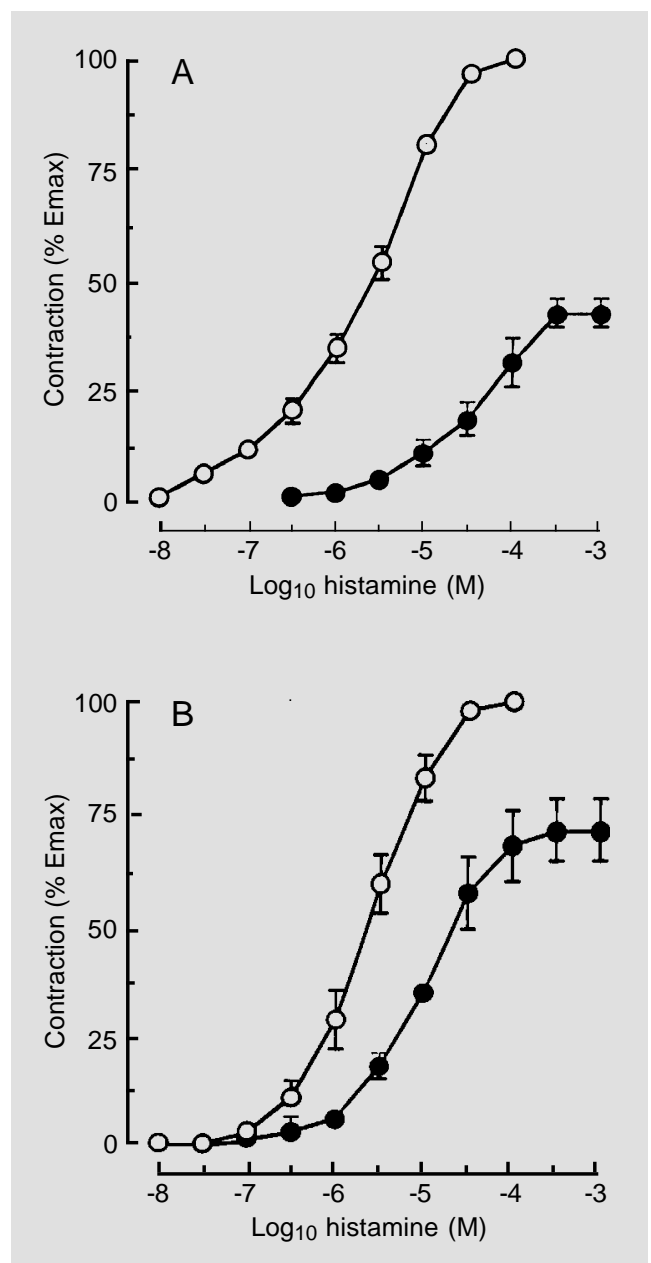

Figure 1 - Concentration-effect curves for histamine in the absence (open circles) or presence (closed circles) of L-arginine (100 $\mathrm{mM})(\mathrm{A})$ or D-arginine $(100 \mathrm{mM})$ (B) in guinea-pig isolated trachea. Each point represents the mean of 4-6 observations and vertical bars represent the SEM. Indomethacin $(5 \mu \mathrm{M})$ is present throughout. 
Figure 2 - Concentration-effect curves for histamine in the absence (open circles) or presence (closed circles) of L-lysine (100 $\mathrm{mM}$ ) in guinea-pig isolated trachea. Each point represents the mean of 4-6 observations and vertical bars represent the SEM. Indomethacin $(5 \mu \mathrm{M})$ is present throughout.
Figure 3 - Concentration-effect curves for methacholine in the absence (open circles) or presence (closed circles) of L-arginine $(100 \mathrm{mM})(A)$ or D-arginine $(100 \mathrm{mM})(B)$ in guinea-pig isolated trachea. Each point represents the mean of 4 observations and vertical bars represent the SEM. Indomethacin $(5 \mu \mathrm{M})$ is present throughout.

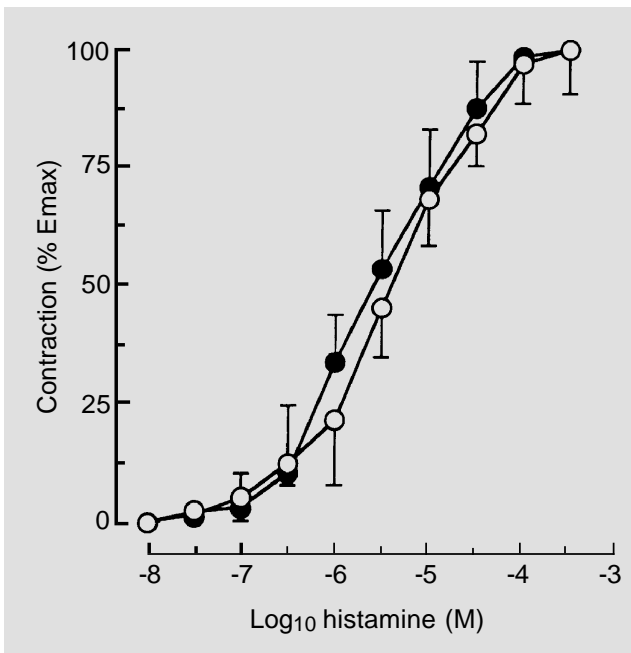

D-arginine $(100 \mathrm{mM})$ significantly reduced the contractile potency $\left(\mathrm{EC}_{30}, 95 \%\right.$ confidence limits; control $1.0 \mu \mathrm{M}(0.4-2.5), \mathrm{N}=4$ $v s$ D-arginine $8 \mu \mathrm{M}$ (5-12), $\mathrm{N}=4, \mathrm{P}<0.05$; Figure 1B) and Emax (control 650 $\pm 190 \mathrm{mg}$ vs $\mathrm{D}$-arginine $475 \pm 140 \mathrm{mg}, \mathrm{N}=4, \mathrm{P}<0.05$ ) of histamine. Following removal of D-arginine from the organ bath, the contractile potency $(\mathrm{P}>0.05)$ and Emax $(\mathrm{P}>0.05)$ of histamine were not significantly different from controls.

In contrast, L-lysine $(100 \mathrm{mM})$ failed to significantly alter the contractile potency $\left(\mathrm{EC}_{30}, 95 \%\right.$ confidence limits; control 1.2 $\mu \mathrm{M}(0.6-2.5), \mathrm{N}=4 v s$ L-lysine $1.2 \mu \mathrm{M}$ (0.82), $\mathrm{N}=4, \mathrm{P}>0.05$; Figure 2) and Emax (control $650 \pm 90 \mathrm{mg} v \mathrm{~s}$ L-lysine $650 \pm 130$ $\mathrm{mg}, \mathrm{N}=4, \mathrm{P}>0.05)$ of histamine.

Both L-arginine (100 $\mathrm{mM})$ and L-lysine $(100 \mathrm{mM})$ significantly reduced the $\mathrm{pH}$ of Krebs-Henseleit solution (control, pH: 7.218 $\pm 0.014, \mathrm{~N}=3$; L-arginine, $\mathrm{pH}: 7.033 \pm$ 0.007, $\mathrm{N}=3$; L-lysine, pH: $6.943 \pm 0.008, \mathrm{~N}$ $=3, \mathrm{P}<0.05$ ).

Methacholine. L-arginine (100 mM) failed to significantly reduce the contractile potency $\left(\mathrm{EC}_{30}, 95 \%\right.$ confidence limits; control $0.47 \mu \mathrm{M}(0.03-6.5), \mathrm{N}=4 v s \mathrm{~L}$-arginine $0.56 \mu \mathrm{M}(0.14-2.2), \mathrm{N}=4, \mathrm{P}>0.05)$ and Emax (control $1.6 \pm 0.4 \mathrm{~g} v s$ L-arginine $2 \pm$ $0.6 \mathrm{~g}, \mathrm{~N}=4, \mathrm{P}>0.05$ ) of methacholine (Figure 3A). Similarly, D-arginine $(100 \mathrm{mM})$ also failed to significantly reduce the contractile potency $\left(\mathrm{EC}_{30}, 95 \%\right.$ confidence limits; control $0.44 \mu \mathrm{M}(0.06-3.2), \mathrm{N}=4 v s \mathrm{~L}$ arginine $0.16 \mu \mathrm{M}(0.04-0.69), \mathrm{N}=4, \mathrm{P}>0.05)$ and Emax (control $1.6 \pm 0.11 \mathrm{~g} v s$ L-arginine $1.6 \pm 0.05 \mathrm{~g}, \mathrm{~N}=4, \mathrm{P}>0.05$ ) of methacholine (Figure 3B).

Potassium chloride. $\mathrm{L}$-arginine $(100 \mathrm{mM})$ failed to significantly alter the contractile potency $\left(\mathrm{EC}_{30}, 95 \%\right.$ confidence limits; control $3.2 \mathrm{mM}(1.7-5.8), \mathrm{N}=6$ vs L-arginine, $2.0 \mathrm{mM}(0.8-5), \mathrm{N}=6, \mathrm{P}>0.05)$ and Emax (control $700 \pm 70 \mathrm{mg}$ vs L-arginine $600 \pm 60 \mathrm{mg}, \mathrm{N}=6, \mathrm{P}>0.05$ ) of potassium chloride. 


\section{Guinea-pig trachea: relaxant responses}

In histamine-contracted guinea-pig tracheal preparations, L-arginine (10-100 $\mathrm{mM}$ ) induced a concentration-dependent relaxation in epithelium-intact and epitheliumdenuded preparations (Figure 4). In the absence of L-NAME, epithelium removal failed to significantly alter the airway smooth muscle potency of L-arginine $\left(\mathrm{EC}_{50} 95 \%\right.$ confidence limits; epithelium-intact, 26.9 $\mathrm{mM}$ (22.4-32.4), $\mathrm{N}=6$ vs epithelium-denuded, $16 \mathrm{mM}$ (13.2-19.1), $\mathrm{N}=6, \mathrm{P}>0.05$; Figure 4A). Similarly, epithelium removal failed to significantly alter the relaxant potency of L-arginine in the presence of LNAME ( $\mathrm{EC}_{50} 95 \%$ confidence limits; epithelium-intact, $26.3 \mathrm{mM}$ (22.9-30.2), $\mathrm{N}=6$ vs epithelium-denuded, $20 \mathrm{mM}$ (16.2-24.5), $\mathrm{N}=6, \mathrm{P}>0.05$; Figure 4B). Furthermore, LNAME failed to significantly attenuate the relaxant potency of L-arginine in epithelium-intact $(\mathrm{P}>0.05)$ or epithelium-denuded $(\mathrm{P}>0.05)$ preparations compared with preparations in the absence of L-NAME.

D-arginine (10-100 $\mathrm{mM}$ ) also induced a concentration-dependent relaxation in epithelium-intact and -denuded preparations (Figure 5). In the absence of L-NAME, epithelium removal failed to significantly alter the airway smooth muscle potency of Darginine $\left(\mathrm{EC}_{50} 95 \%\right.$ confidence limits; epithelium-intact, $36.3 \mathrm{mM}(28.3-46.5), \mathrm{N}=6$ vs epithelium-denuded, $15.1 \mathrm{mM}$ (12.3-18.6), $\mathrm{N}=7, \mathrm{P}>0.05$; Figure 5A). Similarly, epithelium removal failed to significantly alter the relaxant potency of $\mathrm{D}$-arginine in the presence of L-NAME $\left(\mathrm{EC}_{50} 95 \%\right.$ confidence limits, epithelium-intact, $18.6 \mathrm{mM}$ (14.823.4), $\mathrm{N}=5$ vs epithelium-denuded, 16.2 $\mathrm{mM}$ (13.2-19.5), $\mathrm{N}=6, \mathrm{P}>0.05$; Figure 5B). Furthermore, L-NAME failed to significantly attenuate the relaxant potency of D-arginine in epithelium-intact $(\mathrm{P}>0.05)$ or epithelium-denuded preparations ( $\mathrm{P}>0.05)$ compared with preparations in the absence of LNAME.
In contrast to L-arginine, L-lysine (1-100 $\mathrm{mM}$ ) failed to reverse histamine-induced contractile responses in guinea-pig epithelium-intact $(\mathrm{N}=3)$ and epithelium-denuded $(\mathrm{N}=3)$ tracheal preparations (data not shown).

\section{Rabbit bronchus: contractile responses}

L-arginine $(100 \mathrm{mM})$ significantly reduced the contractile potency $\left(\mathrm{EC}_{30}, 95 \%\right.$ confidence limits; control $10 \mu \mathrm{M}(5.5-18), \mathrm{N}$ $=8 v s$ L-arginine, $160 \mu \mathrm{M}(91-275), \mathrm{N}=8$, $\mathrm{P}<0.05$ ) and Emax (control, $900 \pm 160 \mathrm{mg} v \mathrm{~s}$ L-arginine $300 \pm 60 \mathrm{mg}, \mathrm{N}=8, \mathrm{P}<0.05)$ of

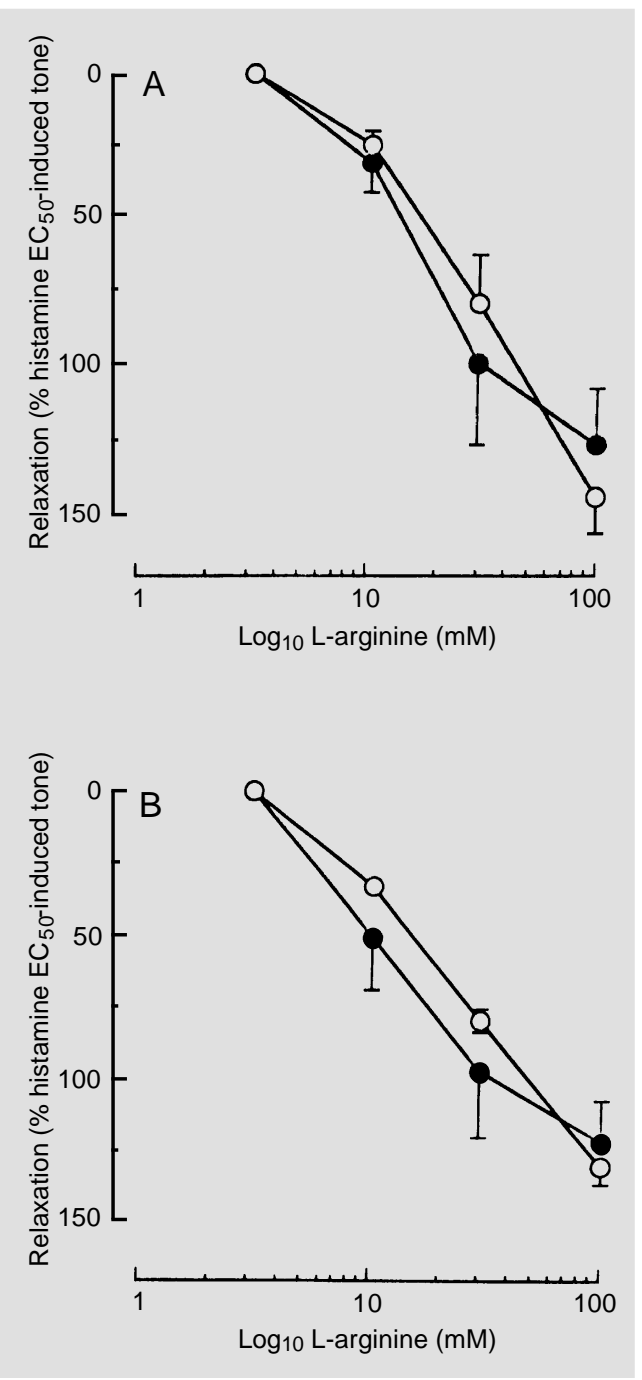

Figure 4 - Relaxation concentration-effect curves for L-arginine in absence (A) and presence (B) of L-NAME $(50 \mathrm{mM})$ in epithelium-intact (open circles) and epithelium-denuded (closed circles) guinea-pig isolated trachea precontracted with histamine $\left(E_{50}\right)$. Each point represents the mean of $5-6$ observations and vertical bars represent the SEM. Indomethacin $(5 \mu \mathrm{M})$ is present throughout. 
Figure 5 - Relaxant response curves for $\mathrm{D}$-arginine in the absence $(A)$ and presence $(B)$ of $L$ NAME $(50 \mu \mathrm{M})$ in epithelium-intact (open circles) and epithelium-denuded (closed circles) guinea-pig isolated trachea precontracted with histamine $\left(E_{50}\right)$. Each point represents the mean of 5-6 observations and vertical bars represent the SEM. Indomethacin $(5 \mu \mathrm{M})$ is present throughout.
Figure 6 - Concentration-effect curves for histamine in the absence (open circles) or presence (closed circles) of L-arginine (100 $\mathrm{mM}$ ) in rabbit isolated bronchus. Each point represents the mean of 8 observations and vertical bars represent the SEM. Indomethacin $(5 \mu \mathrm{M})$ is present throughout.
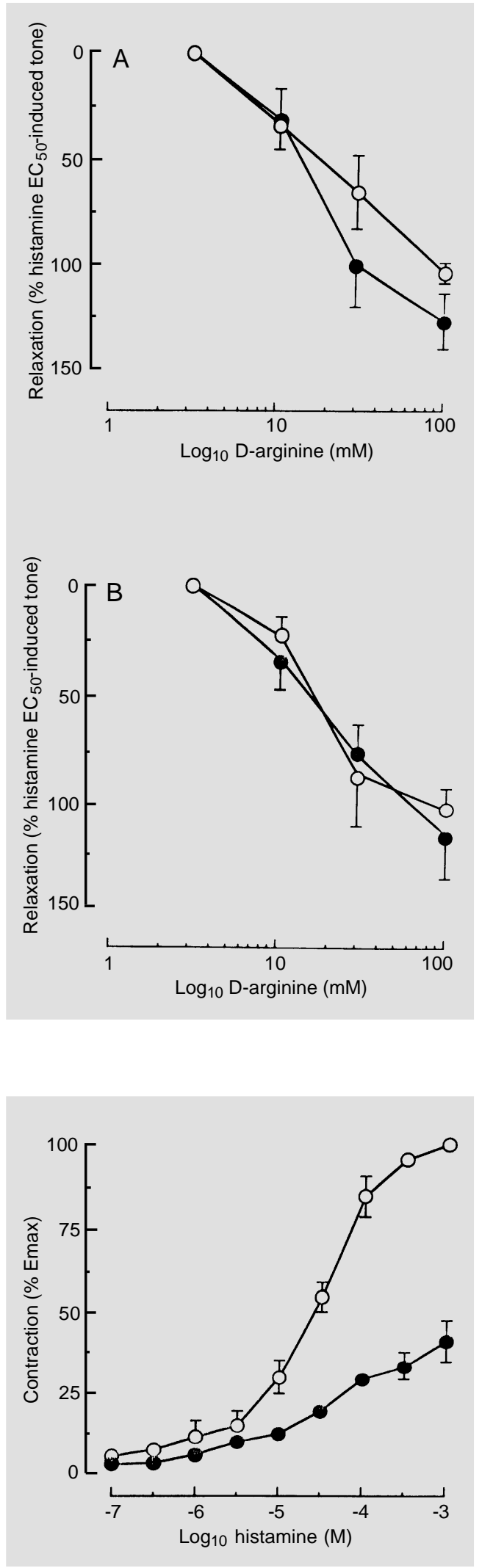

histamine (Figure 6). Following removal of L-arginine from the organ bath, the contractile potency of and the contractile response to histamine were not significantly different from control $(\mathrm{P}>0.05)$.

\section{Discussion}

We have demonstrated that high concentrations $(100 \mathrm{mM})$ of L- and D-arginine, but not L-lysine, reduced the Emax of histamine in guinea-pig isolated tracheal ring preparations, consistent with non-competitive antagonism of the contractile response to histamine. The same high concentration of Larginine was also shown to reduce histamine responsiveness in rabbit bronchial preparations. Furthermore, in guinea-pig tracheal preparations the contractile response to histamine was reversed by L- and D-arginine in a concentration-dependent manner that was epithelium-independent and not mediated by L-NAME-sensitive pathways. In contrast, Llysine did not relax tissues precontracted with histamine. Thus, it appears that L- and D-arginine can specifically interact with $\mathrm{H}_{1}$ receptors and/or the microenvironment to selectively attenuate histamine-induced airway contractile responses.

A number of studies have demonstrated the ability of L- but not D-arginine to reverse the effect of nitric oxide synthase inhibitors on vascular smooth muscle relaxation (7) and on cholinergic nerve-induced contraction (8). Recently we have shown that LNAME $(0.1 \mu \mathrm{mol} / \mathrm{site})$ inhibited bradykinin and histamine-induced plasma protein extravasation in guinea-pig skin (1). L-arginine (10 $\mu \mathrm{mol} / \mathrm{site})$ reduced the inhibitory effect of L-NAME on the bradykinin but not on the histamine response (1). In the absence of a nitric oxide synthetase inhibitor, high concentrations of L- and D-arginine also directly inhibited histamine-induced plasma protein extravasation in the skin and histamine-induced contraction of guinea-pig isolated ileum (1). This was most likely a conse- 
quence of a non-competitive effect of Larginine on $\mathrm{H}_{1}$-receptors. Indeed, the lack of involvement of the nitric oxide synthetase pathway in this response is demonstrated by the lack of stereoselectivity observed between the effect of L- and D-arginine on histamine-induced contraction. In contrast, the nitric oxide synthase inhibitors L-NAME and $\mathrm{N}^{\mathrm{G}}$-monomethyl-L-arginine (L-NMMA) augmented histamine-induced bronchoconstriction in guinea-pigs that was reversed by aerosolised L- but not D-arginine, respectively (4). However, the effects of L- and Darginine on histamine responsiveness in the absence of a nitric oxide synthetase inhibitor was not reported (4).

The ability of both L- and D-arginine to antagonise the histamine-, but not methacholine- or potassium chloride-induced contraction of epithelium-denuded guinea-pig trachea reported here is consistent with the ability of high concentrations of L- and Darginine to inhibit the histamine- but not bradykinin-induced contraction of guineapig isolated ileum (1). Furthermore, the inhibitory response to these amino acids was non-competitive in nature and not dependent on charge as judged by the inability of Llysine to inhibit the airway contractile response to histamine which we have also documented in the ileum (1). The inhibitory effect of L-arginine on the histamine-induced contraction could not be attributed to a fall in the $\mathrm{pH}$ of the Krebs-Henseleit solution, since L-lysine, which produced a similar effect on $\mathrm{pH}$, failed to alter the contractile response to histamine in guinea-pig isolated trachea (this study) or guinea-pig ileum (1). Furthermore, the inability of L-and D-arginine to alter the contractile response to methacholine and potassium ions indicates that the action of these amino acids is not attributable to a nonspecific effect on airway smooth muscle function per se. The interaction between Larginine and the $\mathrm{H}_{1}$-receptor in airways is also not species dependent since a similar result was observed in rabbit isolated bron- chus, although it should be noted that Larginine does not inhibit histamine-induced plasma exudation in rabbit skin (3). This latter observation implies that the effect of L-arginine is not merely due to a chemical interaction with histamine.

Both L- and D-arginine reversed the histamine-induced contractile response by a mechanism that was epithelium-independent and not L-NAME-sensitive. L-lysine failed to relax histamine-contracted tissues, ruling out the possibility that transient changes in bath $\mathrm{pH}$ may have influenced smooth muscle tone. These data are also consistent with an interaction between high concentrations of $\mathrm{L}$ - and $\mathrm{D}$-arginine and the $\mathrm{H}_{1}$-receptor but do not confirm the observation that L- but not D-arginine $(360 \mu \mathrm{M})$ relaxed histamine-induced contraction of guinea-pig perfused trachea denuded of epithelium and in the presence of L-NAME (4). The use of ring preparations, as opposed to tracheal segments, might account for the different findings since epithelium-derived nitric oxide might alter the permeability of the airway epithelium to various spasmogens that would not be a factor with ring preparations. The contractile response to methacholine or carbachol but not serotonin, leukotriene $\mathrm{D}_{4}$ or arecoline was increased in the presence of L-NAME in guinea-pig perfused tracheal preparations (4). Whether differences in the lipophilicity of these agents $(9,10)$ or their ability to simulate the release of nitric oxide (4) can account for these differential effects is not clear.

It was of interest that L-arginine was able to relax histamine-contracted tissues at concentrations that did not have any significant effect in antagonising the concentration-effect curve for histamine. This differential ability of L-arginine to reverse histamineinduced contractile responses compared with its effect on the histamine concentrationeffect curve is analogous to the inability of the beta ${ }_{2}$-adrenoceptor agonist, salbutamol, to shift the concentration-effect curves to 
acetylcholine in human bronchus at concentrations which reversed acetylcholine-induced contractile responses (10) and of the phosphodiesterase type IV inhibitor, Ro 201724 , to shift the concentration-effect curve to capsaicin in guinea-pig isolated trachea at concentrations which reversed capsaicin-induced contractile responses (11). These findings can be explained in terms of functional antagonism $(12,13)$. Thus, if the receptorsubeffect response relationship to L-arginine has a much lower reserve than for histamine then one may expect only minimal antagonism of the concentration-effect curve for histamine. However, despite the lower reserve for L-arginine compared with histamine, L-arginine possesses a sufficient stimulus to reverse the contractile response to histamine.

In conclusion, we have demonstrated the ability of high concentrations of L- and Darginine to interact with $\mathrm{H}_{1}$-receptors in a non-competitive, reversible manner that is unrelated to changes in bath $\mathrm{pH}$, chemical antagonism, charge or non-specific smooth muscle effects in airway tissue.

\section{References}

1. Paul W, Douglas GJ, Lawrence L, Khawaja AM, Perez AC, Schachter M \& Page CP (1994). Cutaneous permeability responses to bradykinin and histamine in the guinea-pig: possible differences in their mechanism of action. British Journal of Pharmacology, 111: 159-164.

2. Frey EK, Kraut H \& Werle E (1950), Kallikrein Padutin. Ferdinand Enke, Stuttgart.

3. Paul W, Perez AC, Page CP \& Schachter $M$ (1994). L-arginine and plasma extravasation in rabbit skin: an effect on bradykinin but not on antigen or histamine. British Journal of Pharmacology, 112: 232P (Abstract).

4. Nijkamp FP, Van Der Linde HJ \& Folkerts G (1993). Nitric oxide synthesis inhibitors induce airway hyperresponsiveness in the guinea pig in vivo and in vitro. American Review of Respiratory Disease, 148: 727734.

5. Goldie RG, Papadimitriou JM, Paterson JW, Rigby PJ, Self HM \& Spina D (1986). Influence of the epithelium on respon- siveness of guinea-pig isolated trachea to contractile and relaxant agonists. British Journal of Pharmacology, 87: 5-14.

6. Raeburn D, Hay DWP, Robinson VA, Farmer SG, Flemming JW \& Fedan FS (1986). The effect of verapamil on isolated airway smooth muscle preparations lacking in epithelium. Life Sciences, 38: 809-816.

7. Moncada S, Palmer RMJ \& Higgs EA (1991). Nitric oxide: physiology, pathophysiology, and pharmacology. Pharmacological Reviews, 43: 109-142.

8. Belvisi MG, Stretton D \& Barnes PJ (1991). Nitric oxide as an endogenous modulator of cholinergic neurotransmission in guinea-pig airways. European Journal of Pharmacology, 198: 219-221.

9. Jeppson A-B, Lofdahl C-G, Waldeck B \& Widmark $E$ (1989). On the predictive value of experiments in vitro in the evaluation of the effect duration of bronchodilator drugs for local administration. Pulmonary Pharmacology, 2: 81-85.
10. Advenier C, Candenas M-L, Naline E \& De Vos C (1991). The effect of cetirizine on the human isolated bronchus: interaction with salbutamol. Journal of Allergy and Clinical Immunology, 88: 104-113.

11. Spina D, Harrison S \& Page CP (1995). Phosphodiesterase isoenzymes regulate non-adrenergic non-cholinergic contraction in guinea-pig isolated main bronchus. British Journal of Pharmacology, 116: 2334-2340.

12. Van Den Brink FG (1973). The model of functional interaction. I. Development and first check of a new model of functional synergism and antagonism. European Journal of Pharmacology, 22: 270-278.

13. Van Den Brink FG (1973). The model of functional interaction. II. Experimental verification of a new model: The antagonism of B-adrenoceptor stimulants and other agonists. European Journal of Pharmacology, 22: 279-286. 